Originalni naučni rad

Godina XIII

Broj 1

Str $38-46$

doi: 10.5937/poseko15-21517

Prof. dr Marko Malović ${ }^{1}$

Univerzitet Edukons, Fakultet poslovne ekonomije, Sremska Kamenica Novi Sad

\title{
SIMPLE ECONOMICS OF THE US-CHINA TRADE WAR
}

"Man is an animal that makes bargains." -Adam Smith-

\begin{abstract}
United States and China have recently found themselves engulfed in a full-blown trade war of epic proportions. This paper explores the probability that outcomes will match the expectations of their protagonists, weighs certain and likely costs along with potential gains for either side and discusses possible consequences for multilateral trading system as we know it. Moreover, paper reiterates why this trade war cannot have clear winners as well as why trade wars can never serve as sustainable and meaningful substitutes for well-meaning trade talks. Finally, article ends on a warning: trade war may easily contribute to already sinister outlook of yet another global financial crisis appearing on the horizon.
\end{abstract}

Key Words: Trade war, United States, China

Invoked by president Trump's pre-election populist promises, propped up by dubious 'national security' grounds and sparse (but probably reliable) evidence of sometimes hidden state-subsidies, (declining) unfair trade practices and/or occasional Chinese abuse of US firms' intellectual property rights, United States and China ${ }^{2}$ have recently found themselves engulfed in a tit-for-tat trade war of ever larger scale.

\footnotetext{
1 marko.malovic@educons.edu.rs

${ }^{2}$ which together with the also affected EU and the rest of NAFTA for all practical purposes make up the better part of the world economy
} 
First it was about solar panel imports and washing machine imports adversely affecting the US industries. Then it became about Chinese (inter alia) aluminium and steel being national security threats under Section 232 of the US Trade Expansion Act of 1962. It has all along been a flat out disagreement on unfair trade practices in technology transfer and intellectual property rights protection or lack thereof. Soon enough, the trade war escalated onto automobile industry and cars trade. Last but not least, both parties have had to hold the fort and try to minimize the losses incurred by trade reduction, mirror-image of which frequently impliedsubsidizing domestic industries that have fallen prey of the developing trade war.

Now, immediate questions of legitimate concernarguably are the following three: 1) Would these protectionist tariff-raising policies deliver a job-creating expansionary effect on the US economy?; 2) How likely is PRC's retaliation to cause equivalent or bigger damage to the US from the one China is forced to withstand (and does that further propel additional economic backlash to Chinese economy all things equal)?; finally 3) What might be the corollaries for the multilateral trading system as a whole if this madness persisted or degenerated into a full-blown trade war?

The answer to the first question is in all likelihood no, quite to the contrary. Here's why. The US is currently at the brink of full employment anyway, fiscal expansion is less justifiable than a decade ago, whereas eo ipso expected (swifter and of course contractionary) monetary response by the FED would be defying the purpose of the exercise. Even if initial protectionist shots (i.e. sky-rocketing tariffs) kept cheaper Chinese competition at bay, consequent retaliation against the US exports will inevitably cost jobs across American tradable industries soon enough. On a top of that, Trump's tariff hikes have been largely targeting intermediate goods as well, thereby subsequently increasing the price of domestic final productsand rendering them less export-competitive and less sought for even domestically, which implies that whatever initial gains in job creation within primary products sector (agriculture, extracting, metal producing) there may be, they are likely to be annulled by job losses in higher-end (more value-added) industries. Hence, this trade experiment will almost certainly result in a financial loss as measured by the US trade balance (and trade gap might easily jump from 500 billion US\$ to much higher number) [Krugman, 2018]. Investment restrictions and dispute settlement procedures within WTO (left in shadows of ostentatious tariff jumps) indeed represent much wiser and less disruptive -if underutilized-course of action on behalf of the US. Some WTO dispute settlement procedures have indeed been launched by both parties, but so far not with an indisputable intention to resume trade talks in good faith, more like in order to a) cause greater economic damage, b) feed domestic electorates 
with additionally heated up rhetoric and c) formally justify actions already taken against the other trading partner.

The answer to the second question is probably affirmative and here's why. Notwithstanding the fact that the first Chinese response was vindictive and pretty much followed American suite, before too long Chinese rectified their retaliatory list so as to remove the additional tariffs levied on goods they cannot easily substitute from elsewhere and adding more of those that they can supply from other countries. By raising tariffs on Chinese exports to the US, Americans have been shooting themselves in the foot, effectively rejecting the benefits of globalisation that primarily US companies have made possible on the Chinese soil. ${ }^{3}$ PRC's Achilles foot, however, is her heavy dependence on foreign semiconductors as an input for many strands of higher-tech production (some $70 \%$ of annual needs are being imported mostly from the US). Moreover, China is one of the biggest foreign national holders of US public and private securities. By inflicting losses with its protectionist retaliation, US is likely to cause PRC a non-negligible loss in the value of those assets and therefore hurt its own American interests in the course of the trade war. Similar arguments go for Chinese FDI in the US and their real estate holdings in America.

Be that as it may, the endurance bottom line in my opinion is greater resilience of Chinese consumers (as compared with their American counterparts) and stronger political pressure that US-based big businesses and general public can exert upon their political leadership, as opposed to more comfortable political manoeuvre space (and more versatile non-tariff retaliation arsenal)enjoyed by president Xi Jinping. Truth be told, China exports almost four times as much to the US as the US ships out to the PRC, hence Chinese are slowly running out of US merchandise to burden with additional tariffs. This is why PRC officials turn to non-tariff barriers, slapping still higher tariffs on products already black-listed, or simply to hitting the nerve by blocking their own exports of key components required by large American companies [The Guardian, 2018].In the end of the day, however, US-China trade war cannot and will not have clear winners.

At last, to answer the third question, WTO and its multilateral rulesbased system, already in deep crisis for some time, should the US and China decide to abandon it, may gradually dwindle into irrelevance. The sheer nature of globalisation (and complicated global value chains it's made of), forcefully implies that the rising US deficit with China is in all honesty not really with China but with the entire Pacific rim (much of Asia, notably Japan and

\footnotetext{
${ }^{3}$ With 130 billion US $\$$ of exports p.a. in 2017, China is the third biggest export market for the US, and actually the first outside NAFTA, in fact in the last year before the trade war alone, the US exports to China increased circa 13\%, while from 2002-2017 US exports to China increased for almost 500\% [Morrison, 2018]!
} 
Taiwan), whose various raw materials, components and intermediate products eventually gather in many - yes Chinese, but above all- multinational (or indeed US) factories located in PRC [Morrison, 2018].The turmoil and lawlessness brought about by American countervailing of globalisation and of open world trade could be much worse and far greater than the effort and cost of US transition to more autarky. Thus, Trump tariffs are primarily hurting multinational and frequently American own rather than Chinese supply chains, and therefore are bound to backfire i.e. hurt US technology competitiveness before too long [Lovely-Liang, 2018]. Disruption of international supply chains is in turn unpredictable, highly contagious and for that reason difficult to imagine without causing another global economic contraction. Multilateral, rule-based pro-liberal trading system is nowhere near perfect, ${ }^{4}$ and should be reformed to limit unilateral creative behaviour of the rich and powerful, including both US and PRC, but trade liberalisation and multilaterally accepted rules of commerce are too important a legacy to be destroyed over two countries' disagreement, however big and important they are [The Economist, 2018].

Hence, instead of neck-a-neck clash in a sort of Prisoners' dilemma constellation[Krugman-Obstfeld-Melitz, 2012] -even though this trade war game appears to be sequential (in other words, of the extensive form) rather than of strategic, simultaneous single shot nature- both countries should seek ways to reopen constructive negotiations focusing on a minimum concessions transfer from the PRC to the US which would restore and maintain reasonably free trade. In practice, aforementioned trade concessions typically ought to come in the shape of trade and investment policy reforms in emerging market country (i.e. China) to do with protecting intellectual property rights, foreign investors' claims and managing domestic macroeconomy[Bond-Park, 2001]. However, in hands-on modeling international trade they are oftentimes captured as unilateral direct transfers of value (numeraire being chief or representative consumption good exchanged between the two countries). For instance, Ljungqvist and Sargent (2004) define trading partners' payoff functions as linear combination of their respective utility functions and expected transfer being subtracted from -in our case- the PRC's or added to in our case- American aggregate utility.

In a resembling fashion, Grosmann and Helpman (1995) introduced strategic trade policy clash between two equally big economies, yet with several important and useful analytical extensions. First of all, it's vital to realise interaction between various lobby groups and politicians in power within the country as pertinent for the international trade policy stance, so that

\footnotetext{
${ }^{4}$ After all, raising tariffs to unprecedented levels on national security grounds is an antilibertarian design flaw allowed by the very WTO Treaty's article XXI.
} 
governments' objective function consists to the extent of the well-being and satisfaction of average voter/consumer and to a great deal also of the sum of contribution schedules provided to the politicians by the interested and organised industries.Second, by imposing ad valorem tariffs or to the contrary by subsidising trade alike, governments drive a wedge between domestic and offshore prices, thereby facilitating international trade policy as a potential tool for income redistribution. The authors characterise the equilibrium domestic trade policy response to an arbitrary foreign policy vector, by maximizing the joint welfare of government and each individual industrial lobby, while contribution schedules of all other lobbies are taken as given. Trade policy response vectors of two countries are henceforth treated as system of simultaneous equations. System of equations, in turn, boils down to manipulation and interplay between ad valorem trade tax and subsidy rates which represent political support and terms of trade motives for trade intervention [Grosmann-Helpman, 1995, p. 688]. International equilibrium point therefore lies at the intersection of the two best response functions. The trouble is that political equilibrium in a trade war departs from a theoretical equilibrium because politically motivated governments tilt trade policies in favour of their organised industrial groups, by means of higher home tariff and lower foreign export tax (if not indeed offering a subsidy even) than suggested in a theoretical equilibrium [Ibidem, p. 692]. This is why trade wars cannot possibly serve as a sustainable and meaningful substitute for trade talks.

Latest developments in US-China trade negotiations concentrate primarily around peculiar deadlock in appointments to WTO's appellate body, basically vetoed by the United States which accuses the dispute settlement body's judges of hampering the US campaign against what has been described as unfair trade practices, according to Payosova, Hufbauer and Schott (2018). Either unilaterally, or by solidifying an informal contact group of "China losers" that comprises the US, Japan and the EU, Americans are trying to crack down on Chinese alleged currency manipulation, forced technology transfer and abundant subsidisation of domestic firms. However, as justly put forward by Gros (2018), these arguments are largely a misnomer, since there is evident albeit sluggish improvement in liberalisation of trade and investment practices of Chinese firms and state as opposed to what have been done in the past. In light of shifting balance from exports to domestic consumption and ambition to champion renminbi into the leading world currency, yuanis much less managed than before. By the same token, joint ventures preferred over conventional FDI by the PRC simply require sharing of know-how as well as technology transfer between the business partners in order to be given entrance to the gigantic Chinese market, thereby striking a more realistic balance of needs to protect one's intellectual property rights and on the other hand to enable bridging the international growth gap.This is not to deny that PRC's 
non-tariff barriers have been and still are violating the spirit of multilateral trade rules, especially by restricting foreign companies' access to its market unless they hand over valuable high-end technology [Krugman, 2019]. Interestingly enough, in terms of non-tariff barriers, research done by Global Trade Alert Observatory suggests that the US enacted more restrictions to bilateral trade per year than China did from 2008 to this day [Gros, 2018].

Hence, if thetrigger -for standing up to somewhat legitimate developing country's catching up instruments of industrial policy, which in all honesty did not bother while western technological supremacy used to more than compensate for Chinese meddling with fair trade setting- is in fact fairly hefty trade surplus of PRC accumulated in bilateral trade with the US, then everything could and probably shall be resolved with some modest reforms and thus some modest concessions allowed for by Chinese side. For example, PRC has been taking small steps to boost intellectual property protection and lift caps on foreign ownership of firms in China for some time now. But these are improvised measures meant to reward friendly countries or reassure investors, what's more, they are largely in line with president Xi's broader reform agenda that would have been carried out anyway. They aren't going to fundamentally change anything about the Chinese model, and thus they are unlikely to satisfy the deep state in D.C. [Orchard, 2018]. As amply explained by Krugman (2019), for better or worse, business people in the US and president Trump himself (perhaps for different reasons) are ready to settle for less.

That notwithstanding, if the real trigger for Sino-American stand-off is the fact that competitiveness gap between PRC and USA is of late closing much faster than the Chinese regulatory environment is converging [Gros, 2018], in other words, that the quality and characteristics of Chinese products are recently too close for comfort, then Washington may well continue creating incentives for MNCs to reroute supply chains outside China or encouraging US exporters to tailor their products to other markets [Orchard, 2018]. Again, it is fair to mention that China's dependence on the US market has strategically begun shrinking even before the trade war broke out, which leaves China with little choice but to shift focus onto enhancing her market share in Europe, while hoping that growing consumption at home ${ }^{5}$ will ease the overseas pain [Orchard, 2018],[Sachs, 2018].After all, in tune with takeaways of Ricardo-Torrens trade theory, international commerce doesn't necessarily have to be and often isn't a zero-sum game. Both the US and China could have vibrant tech sectors that could benefit from each other's

\footnotetext{
${ }^{5}$ At the start of this decade, Chinese government statistics showed that domestic consumption accounted for $38 \%$ of GDP, but by the end of 2017, that figure had risen to 42 43\% [O'Neill, 2018].
} 
innovations. Moreover, in a post-globalised world, China's economy still is a key driver of growth in many other countries, including the US [O'Neill, 2018].

However, there is a growing concern that on a deeper level the Trump administration's conflict with China has nothing to do with US external imbalances, state-controlled Chinese market, nor with China's alleged theft of intellectual property. It may have everything to do with containing China as the re-emerging global powerhouse, by limiting its access to foreign markets, cutting-edge technologies, global banking services, and perhaps even US universities [Sachs, 2018, p.1]. This in turn implies that simple economics of a trade war ceases to be simple (or economics for that matter) any more, whereas another cold war commences before our eyes instead, with unforeseen geopolitical and even military consequences in the near future. When technological supremacy does not imply economic upper hand no more, but rather a strategic twist in military might and hence political power, first principles of economics may not apply any longer, not because there's anything wrong with them but because entirely different game could be afoot.

At last, but by no means the least important, raging trade war between the US and the PRC is causing whiplashes of all the major world currencies in that their oscillation is even changing direction several times per week. Tax cuts, fall of unemployment and increased wages (and overall purchasing power) in the US have provoked rising interest rates and consequently appreciation of the US dollar. These developments together have already provoked several foreign debt and currency crises across the globe, most notably in Argentina, Venezuela and Pakistan. In addition, protracted crude oil price hike (at about 80US\$ per Brent) might easily endanger financial health of developing countries further still, with another recession or even fullfledged global financial meltdown arguably lurking from the unsettling future. It is debatable how well prepared world is for the next international financial crisis, if it were to catch us chin-deep in unnecessary and ground-breaking trade war.

\section{REZIME \\ PROSTA EKONOMIKA TRGOVINSKOG RATA IZMEĐU SAD I KINE}

Sjedinjene Države i Kina odnedavno su u totalnom trgovinskom ratu epskih proporcija. Ovim člankom ispitali smo verovatnoću ishoda kakvim se protagonisti trgovinskog rata nadaju, odmerili smo izvesne i izgledne troškove nasuprot potencijalnih koristi na obe strane, kao i prodiskutovali moguće posledice po multilateralni trgovinski sistem kakav je postojao do 
izbijanja trgovinskog rata. Nadalje, u članku se obrazlaže zašto trgovinski rat SAD i Kine ne može i neće imati nedvosmislenog pobednika, kao i zašto trgovinski ratovi nikada ne mogu biti pouzdan i smislen supstitut za trgovinske pregovore u dobroj veri. Najzad, članak završava upozorenjem: trgovinski rat može lako doprineti već zlokobnom stanju svetske privrede i prizvati još jednu međunarodnu finansijsku krizu što se nazire na horizontu.

Ključne reči: trgovinski rat, SAD, Kina

\section{REFERENCES}

1. Bond, E.-Park, J.-H.(2001), "Gradualism in Trade Agreements with Asymmetric Countries", Review of Economic Studies, Vol.68, pp. 379406.

2. The Economist (2018), "Briefing: The World Trading System - Trade Blockage", 21st of July, mimeo.

3. Gros, D. (2018), "Are China's Trade Practices really unfair?", The Project Syndicate, December 5th, mimeo.

4. Grossman, G.-Helpman, E. (1995), "Trade Wars and Trade Talks", Journal of Political Economy No. 103, Vol. 4, pp. 675-708.

5. The Guardian (2018), "The Guardian View on US-China Trade Wars: Careful what You start", editorial, 18th of September, mimeo.

6. Krugman, P. (2018), "Opinion", The New York Times Op-Ed, May 31st, mimeo.

7. Krugman, P. (2019), "Trump, Trade and the Advantage of Autocrats", The New York Times Op-Ed, February 25th, mimeo.

8. Krugman, P.-Obstfeld, M.-Melitz, M. (2012), "International Economics Theory and Policy", Addison-Wesley, Ninth Edition, pp. 235-236.

9. Ljungqvist, L.-Sargent, T. (2004), "Recursive Macroeconomic Theory", The MIT Press, Second Edition, Cambridge, MA, pp. 834-838.

10. Lovely, M. -Liang, Y. (2018), "Trump Tariffs primarily hit Multinational Supply Chains, harm US Technology Competitiveness", PIIE Brief 1812, Washington DC, May.

11. Morrison, W. M. (2018), "China-US Trade Issues", Congressional Research Service 7-5700, April 16th, Washington, DC, passim.

12. O'Neill, J. (2018), "Trump's Economic War of Choice", The Project Syndicate, December 13th, mimeo.

13. Orchard, P. (2018), "In the US-China Trade War, a Cease-fire Ends Nothing", Geopolitical Futures, December 5th, mimeo. 
14. Payosova, T. -Hufbauer, G. C.- Schott, J. (2018), "The Dispute Settlement Crisis in the World Trade Organisation: Causes and Cures", PIIE Brief 18-5, Washington DC, March.

15. Sachs, J. (2018), "The War on Huawei", The Project Syndicate, December 11th, mimeo. 